\title{
Application of Hybrid Green Fences for Security in Public Building Designs in Nigeria: Lessons from Kigali, Rwanda and Abuja, Nigeria
}

\author{
"Olatunde Adedayo 1,2, Manlio Michieletto', Eunice Bamidele² and \\ Marie Ntigulirwa'
}

Published online: 15 July 2020

To cite this article: Olatunde Adedayo, Manlio Michieletto, Eunice Bamidele and Marie Ntigulirwa (2020). Application of hybrid green fences for security in public building designs in Nigeria: Lessons from Kigali, Rwanda and Abuja, Nigeria. Journal of Construction in Developing Countries, 25(1): 147-162. https://doi.org/10.21315/jcdc2020.25.1.8.

To link to this article: https://doi.org/10.21315/jcdc2020.25.1.8

\begin{abstract}
The issue of security has become a burning topic and major concern for urban dwellers in many developing countries. The use of active security measures is no longer considered as adequate to forestall the security breaches in many public buildings. It is commonplace in urban areas in developing countries such as Nigeria to find that these public buildings having perimeter walls of solid walls. These practices constitute environmental challenges to the urban planners and the architects who design such buildings. In the case of Kigali, there has been a significant attempt to create a blend of the environment with security walls through the design of the perimeter fences of public buildings. The advantages of these concepts have different approaches which could be adapted for different situations. This article aims to examine the nature of the hybrid fences designs in use in public buildings in Kigali with the view of suggesting advantageous ones for application to ensure environmental sustainability in Nigeria. The research method adopted is a qualitative approach using case studies of selected public buildings in Kigali and buildings in Abuja, Nigeria. The design of these fences would be examined and the different options identified. A comparative analysis would be drawn from the two cities and the areas of applications of the solutions from Kigali would be proposed. The study would conclude that the approach of hybrid green fences in Kigali offers the best advantage of security as it allows for visual contact and serves as the passive role of environmental sustainability while ensuring aesthetic value for the buildings. The article would recommend that architects incorporate the concept of hybrid green fences in the overall design of the public buildings and not as a secondary development.
\end{abstract}

Keywords: Design, Green, Hybrid-fences, Security, Public buildings

\section{INTRODUCTION}

Fences have become an integral part of building design and construction, the purpose they are meant to serve varies amongst countries, cities and property owners. Every building, public or private, has surrounding space within the plot which is used for other activities. The premises are usually demarcated by property line on which a form of demarcation is made using fences from the line of shrubs, trees or kerbs. Land demarcation is believed to be the first activity of humans when they got organised and it was done to serve the purpose of defining the boundaries of a property, the extent of land and the shape of the land (Libecap and Lueck,

\footnotetext{
'Department of Architecture, School of Architecture and Built Environment (SABE), University of Rwanda, Kigali, RWANDA

${ }^{2}$ Department of Architecture, School of Environmental Technology, Federal University of Technology, Minna, NIGERIA

*Corresponding author: arcadedayo@gmail.com
} 
2011). Property boundaries are also defined to ensure that there is no dispute between neighbours as opined by Hull et al. (2016) in explaining the benefits of property demarcation. Over the years as urban centres grew and the demand for land became pronounced, demarcation of property boundaries became more important which is usually the challenge for the Urban Development Boards in many countries.

Public buildings definition could vary depending on the context in which it is applied either in terms of ownership or use. In the case of use, it is expected that it is a building that the general population would have access to with minimum restriction. The design of such building should not offer any form of restriction to the possible users (Oyetola et al., 2015; Anunobi et al., 2016). Research in public building access in the past has focused on access for the physically challenged (Wong, 2014). However, the narrative has changed to inclusive design that seems to ensure that no group of people are denied access to public buildings right from the design stage to its completion (HM Government, 2006; Lee, 2008). The population growth witnessed in many cities of the world has come with the challenge of security equally as many buildings (public and private) now require some form of security be it passive, active or both (Georgiou, 2006; The Protection Engineering Group, Inc., 2011 ; Zhang and $Y u, 2013)$. The common type of passive security measure adopted by many architects in the design of public buildings is in the perimeter fencing of the property such that access is controlled and limited. The materials used for these types of fences are usually monolithic material of either steel, concrete or any other choice. In cases where the materials used for the fences become mixed, such fences are referred to as hybrid fences which have become a common feature in the cities mainly for aesthetic purposes.

The inclusion of some form of active security is included through the use of security guards who man the gates and the use of security cameras as surveillance. There are several forms of application these passive security elements in the design and construction of public buildings in Nigeria and Rwanda. The challenge for the architects in the 21 st century is how to ensure sustainability in the built environment in terms of social and environmental requirements. In the case of Rwanda and Nigeria, it is common to find public buildings such hotels, government buildings, markets, banks, churches and security buildings fenced, however, the point of departure is usually the nature of the fences. This article seeks to examine the nature of fences designs and elements used in selected buildings in Kigali with selected buildings in Abuja with the view determining the application of hybrid green as a viable design choice for public buildings in Abuja.

\section{Security of Public Buildings}

The rate of urbanisation when left unchecked will lead to what Raeisi, Nezhad and Hafezifar (2010) and Zhang and Yu (2013) referred to as social fracture with resultant development imbalance which endangers the urban development of any society where this occurs of which security would now be a major concern for the inhabitants of the city. The growing population is of great impact on the sustainability of the city and many people find their way into the city (Mumovic and Santamouris, 2009). The major evidence of urbanisation of settlement or community is the number and nature of buildings being constructed and the level of infrastructure being provided to serve them. Public buildings are usually a common place accessible to as many people who desire to access the building which often 
affects the security nature of the building and the occupants. The common feature in public building designs is to find some level of segregation of the users in the name of security and privacy (Georgiou, 2006).

It is common to find active security measures being employed in the security of with little attention to passive security measures in the design aside from the regular measures employed by architects in general which should not be the case (Federal Emergency Management Agency, 2003). The general belief is that active security offers the users a sense of security while using passive security the beauty of the building could be misplaced given the design considerations that would be required to be implemented. According to Zahner Group (2017) the beauty of a building when designing a building it is good to always consider how the building could be defended passively in a sustainable manner. The use of specific security building materials was suggested by Meara (2014) which could range from doors, walls, windows and roofs. In choosing the type and nature of security to implement in a public building the nature of the activity and users of such building must be considered as stated by Dorn et al. (2014). The common feature as observed in many buildings and its environment in terms of passive measures for security is the use of perimeter fences which could vary depending on the aim of the architects, the client and the government policy.

\section{Fencing of Public Buildings}

In many cities in the developing countries, the use of fences is usually found in the cities as a means of protecting the building from undue access and also for privacy purpose. In the rural areas or countryside, the use of fences is often none existent as neighbours are allowed to walk through each other properties. There is the belief that communities without fences are better secured as it is difficult for a person to hide his activities from the public view, this is supported by the argument of transparent architecture (Sadeghi, Sani and Wang, 2015). In many public buildings giving the nature of the users, the properties within the buildings and the time of use, it is therefore common to find that the architects usually have the building enclosed with a perimeter fence which serves the purpose of passive security and also demarcating the property line (Libecap and Lueck, 2011). The benefit of the use of the perimeter fence is that it allows for the deployment of active security in specific places such as the gate and corner points of the property. The security personnel could easily be stationed at the security gates to check the users coming in and out of the building in addition to the security cameras that would have been installed. In many public buildings, the use of fences is argued as helping to regulate undue access and also shielding the building from possible attack as access is controlled through the gate.

The nature of the fence designs and the fence construction materials vary according to the city, the architects and the image sought by the clients. The common thing that is expected to be paramount is the need for sustainability in every design and construction decision making in the construction of the buildings. According to Kim and Kwon (2018), sustainability should form the basis for securing the cities, particularly public spaces and by extension public buildings. The issue of sustainability as it affects fences relates directly to the social and environmental aspects as the fence designs and materials could either affect the environmental conditions of the city or the inclusiveness it projects as reflected in the public building design fences. Examples of fences include walled fences, picket fences, 
iron grill fence, wire fence and green hedged fences. It is also possible to find a combination of either of these and the ration of combination varies on several factors such as design, cost, client requirement, availability of materials and law. The need for environmental sustainability usually should play a major role in the selection of the fence type, however, this is often not the case in many developing countries and their cities. The availability of research on the hybrid fence and its application have been very minimal or non-existent however in practice this type of fences is observable. It is a common term used by companies involved in fence provision (see Capital Fence and Wire Ltd., 2017).

\section{RESEARCH METHOD}

A descriptive survey method was adopted for this study. The study areas were Abuja and Kigali cities, both capital of Nigeria and Rwanda because there is a concentration of public buildings in the cities and the cities are still growing. In undertaking the study, literature review and direct observation were used through a case study approach. The selection of public buildings was based on access granted by the authorities in charge of the building but care was taken to ensure that the categories of buildings selected were the same in the two cities. A checklist is used to determine the type and nature of the fences used in the building and then the data obtained were analysed and presented in comparative form. The use of figures in terms of sketches and picture was to provide a graphical representation of what was obtained. The discussion on the finding was based on the selected fence feature and the lessons from the Kigali case study is compared with that of Abuja and relevant deductions are made to support the implementation in Abuja case. The examination of the law governing approval for fence designs in the two cities was examined and tabulated for a quick view of the difference as possible areas of improvement in the case of Nigeria.

\section{RESULTS AND DISCUSSIONS}

In examining the findings of the study, the results are presented and discussed based on selected factors that related to the provision of fences in the overall city development and architectural design. The discussion is based on specific subsection that would show the lessons from the hybrid concept as adopted in Kigali.

\section{Policy Regarding Fences in Kigali}

In examining the policy of Rwanda regarding the use of fences around the property line, the following requirements were extracted from the available policy and law documents. 
Plots may be, but do not have to be enclosed by hedges, wire fences and walls with the following requirements:

1. Impervious fences or wall fences shall be discouraged but where inevitable shall not exceed a height of $2 \mathrm{~m}$.

2. Walls shall be maintained in an optically clean and structurally safe condition.

3. Wire fences shall be of plain wire mesh.

4. Greening in fencing activities shall be encouraged.

5. Broken glass, electrical wire fence, barbed wire or angled top sections of barbed wire shall not be permitted.

6. To ensure the physical security of the neighbourhood, plot boundaries shall be as transparent or semi-transparent as possible.

It is observable that the use of wall fences is being discouraged while greening in fences is encouraged, this forms the basis for the visible use of such greening in fences. The policy also goes ahead to state that to ensure security within neighbourhoods, owners of properties should ensure semi-transparent nature in their fences and this is easily achievable with the greening of the fences. This type of policy can be adopted in the case of Abuja and any other city that does not have a clear policy regarding fences. The policy should always cover the height and the materials used for the fences and what the policy seeks to achieve. There is also the need to ensure that the policy is easily accessible on the websites of the authorities saddled with the responsibility of planning the city and also approving the designs for the buildings.

\section{Setbacks from Road and Infill of Space}

In examining the setbacks between roads and buildings one is quick to notice that these buildings usually obey the regulation both in Abuja and Kigali. It is common practice to find that landowners regardless of the type of building they seek to build often try to fence the entire property. It is therefore common to find that in certain aspects of the cities, the location of the fences could be very close to the road as is the case in residential areas. In the case of government and public buildings, it is common to find that there is an adequate setback of the fence from the road and in the case of Kigali, $6 \mathrm{~m}$ or above from the road as shown in Figure 1. It is observed from Figure 2 that Types A and B setbacks are usually available in areas where traffic is often high and the setback is further divided to accommodate dedicated lanes for bicycles and pedestrians. The provision of a lawn before the bicycle lane serves as a buffer zone, while the second lawn and flower bed serves as a buffer for the fence and pedestrian. This flower bed is used to plant different types of flowers and hedges which in turn help protect the fence and reduce direct visibility into the building premises. The use of these spaces ensures that the setback is not seen as unutilised space which could be commandeered for other purposes.

Type $C$ fence setback is common in places where the traffic is low and the road is smaller. The common feature in Types A, B and C setback is that there is always the provision of lawn/flowerbed space before the fence. Type $D$ fence is common in many roads adjoining the public buildings in Nigeria where little attention is given to the provision of lawn before the fence. The advantage of Types A, B and $C$ is that the strip of this lawns helps improves the environmental sustainability of the 
areas located before the fence, it also ensures that the hybrid fence fits into the overall scheme of the city. The lawn area by the fence is also maintained by the owners of the building, the key lesson here is that the design of the fence setback is often planned along with the landscape requirements of the building. These lawns provided within the setbacks for the fence also ensures that there is a reduction in the heat gain within the city. The security of the building is also improved as people do not get to walk along the fence which could encourage a person to attempt to jump the fence, as the areas are clearly defined.
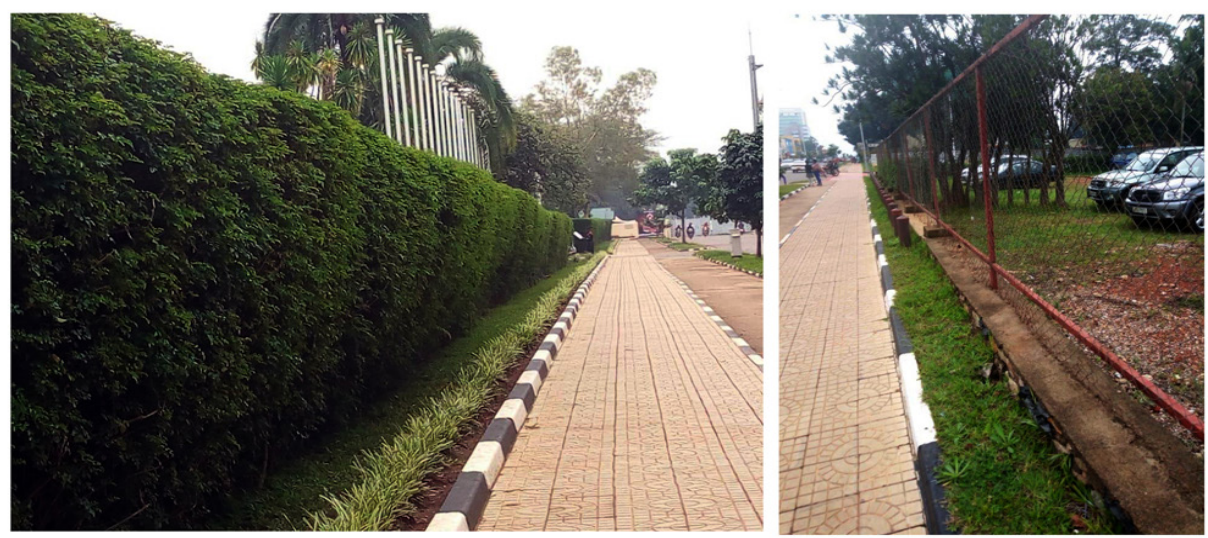

Figure 1. Indication of the Setback from Road and Facilities within the Spaces
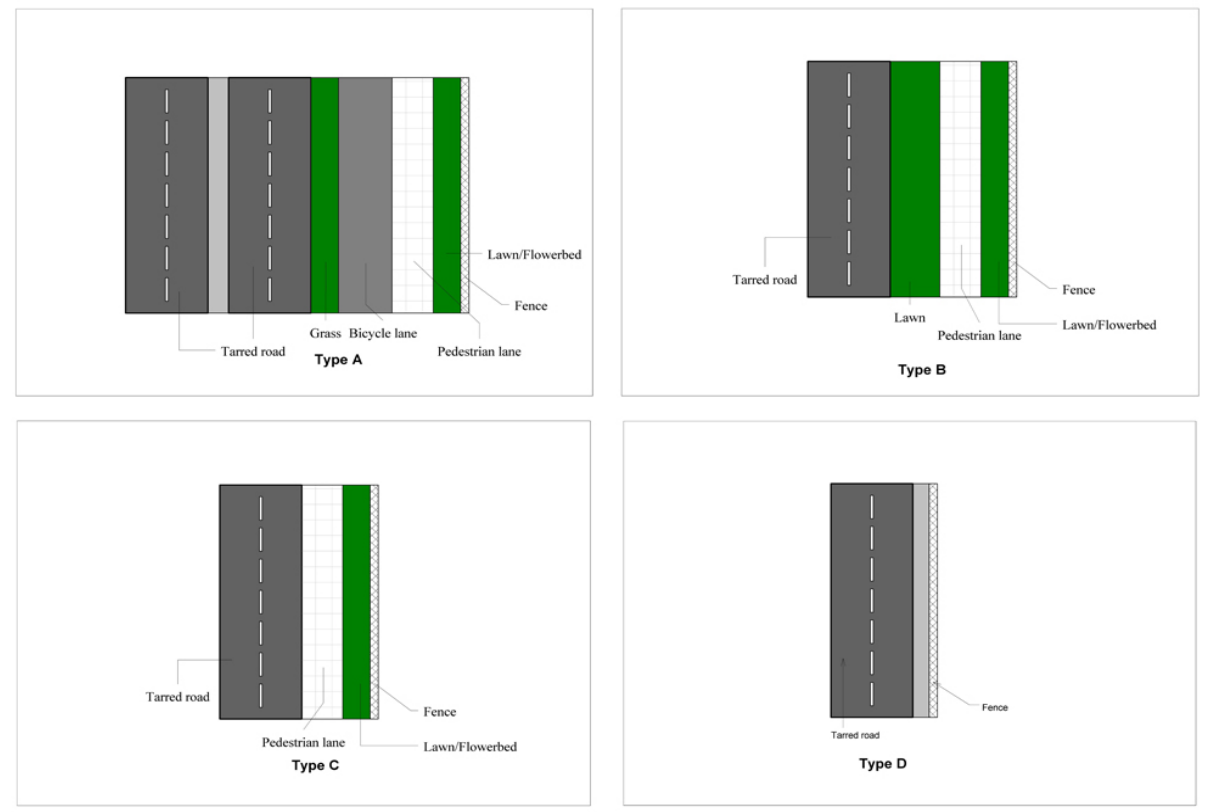

Figure 2. Examples of Different Types of Setbacks in Relation to Fences 


\section{Categories of Fences}

Fences are often named or grouped based on the material or height of the fence, however, this categorisation can become cumbersome. The common type of fence found in Abuja is the walled fence, usually made of either concrete or sandcrete block; the designs could vary depending on what form of beauty the architect seeks to create. There are also examples of fences with iron grill, mesh or a combination of concrete and sandcrete wall as shown in Figure 3. These types of fences usually increase the amount of heat gain and are not considered as being environmentally friendly. The claim is that these types of fences usually ensure no direct visibility to the building premises. There is also the iron grilled fence which is simply the use of iron grill or mesh inserted between concrete columns; this offers a direct view into the premises which could greatly affect the security of the building. There are the mixed iron grill and wall fence; this type usually includes a base wall of a given height which could be as high as $1.8 \mathrm{~m}$ and an iron grill to make up the remaining height. The green fences are usually the type that is made up of a line of hedges planted together at very close intervals, though this type can allow for pedestrians to pass through thereby not ensuring security despite being environmental good. The last category is the hybrid fence as proposed in this article, the key thing is that it incorporates some part of the wall fence at a low level, the iron grill and the green hedges or climbers. Examples of such fences are shown in Figures 3 and 4 where these fences are a common feature in the city of Kigali. These hybrid fences and its variants are considered good for security when they are fully matured as seen in Figures 3 and 4, it allows the architect latitude to design them and improve the aesthetics of the building while ensuring sustainability.
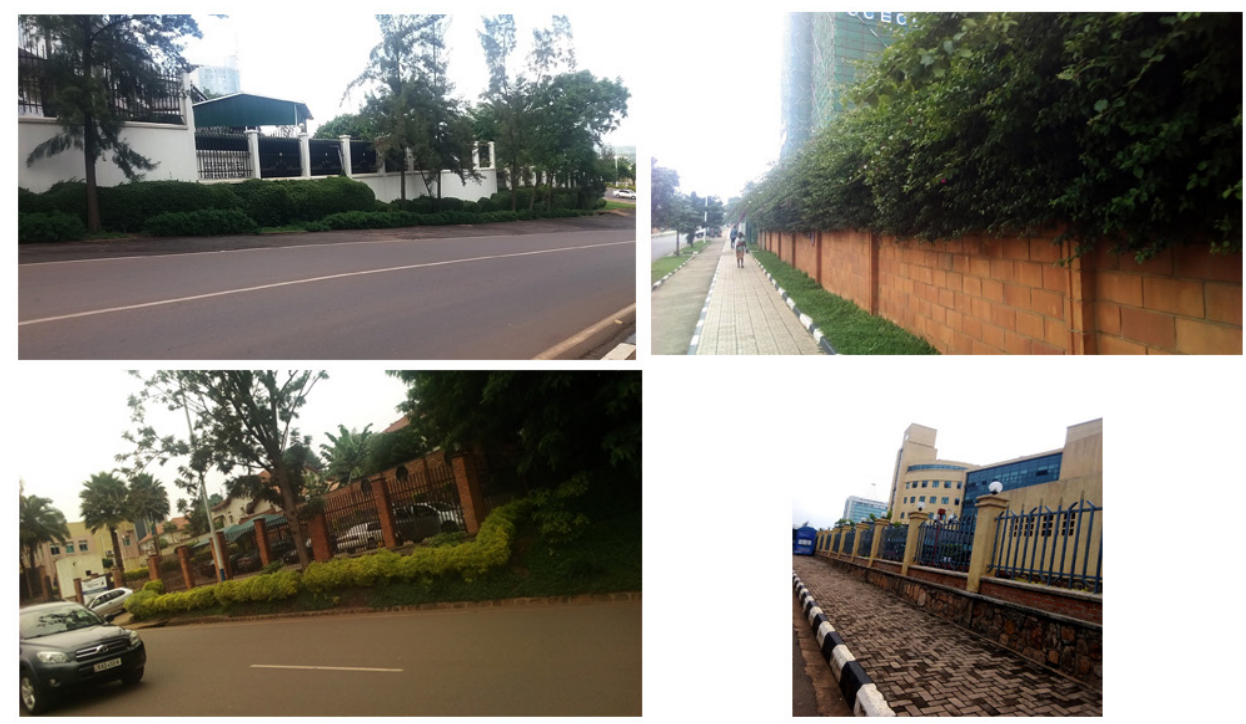

Figure 3. Examples of Fences around Some Selected Public Buildings in Kigali 

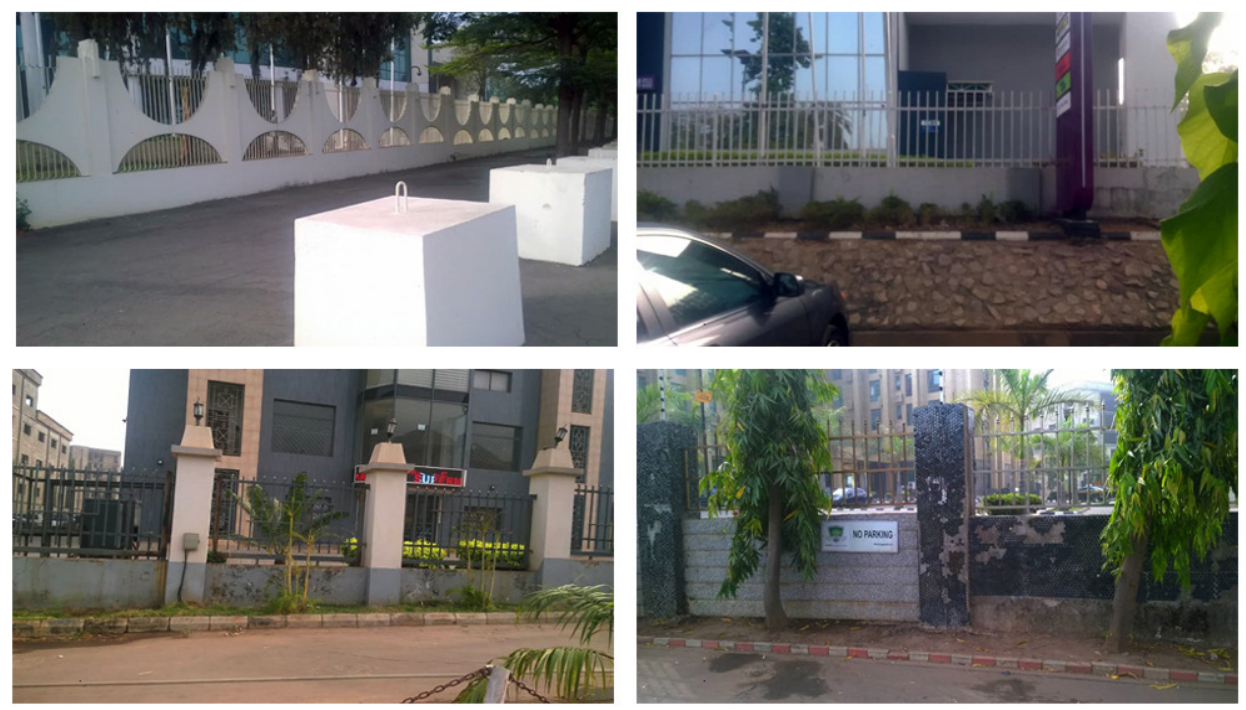

Figure 4. Examples of Fences in Selected Public Buildings in Abuja

\section{The Basic Structure of Fences}

In examining the basic structure of the fences found in cities of Abuja and Kigali, it was easy to find Type $C$ fence structure in Abuja which is made up of either solely concrete or a mixture of concrete and sandcrete block as shown in Figure 5. The coping on the fence is used to create beauty and ensure that water drains away from the building. In the case of Kigali, Types A and B are a common feature created for the climbers to find support. Concrete or bricks are used in the columns to support the iron grill. The iron grill or mesh are produced in compartments to fit the spaces between columns, this allows for easy replacement should the need arise, this ensures that the scheme is sustainable. Examples of such fences are shown in Figure 5 where it is possible to see a fence at the early stage and the one at the finished stage. The advantage of this type of fence structure is that the architect can vary the green plant and also the pattern of the climbers. 


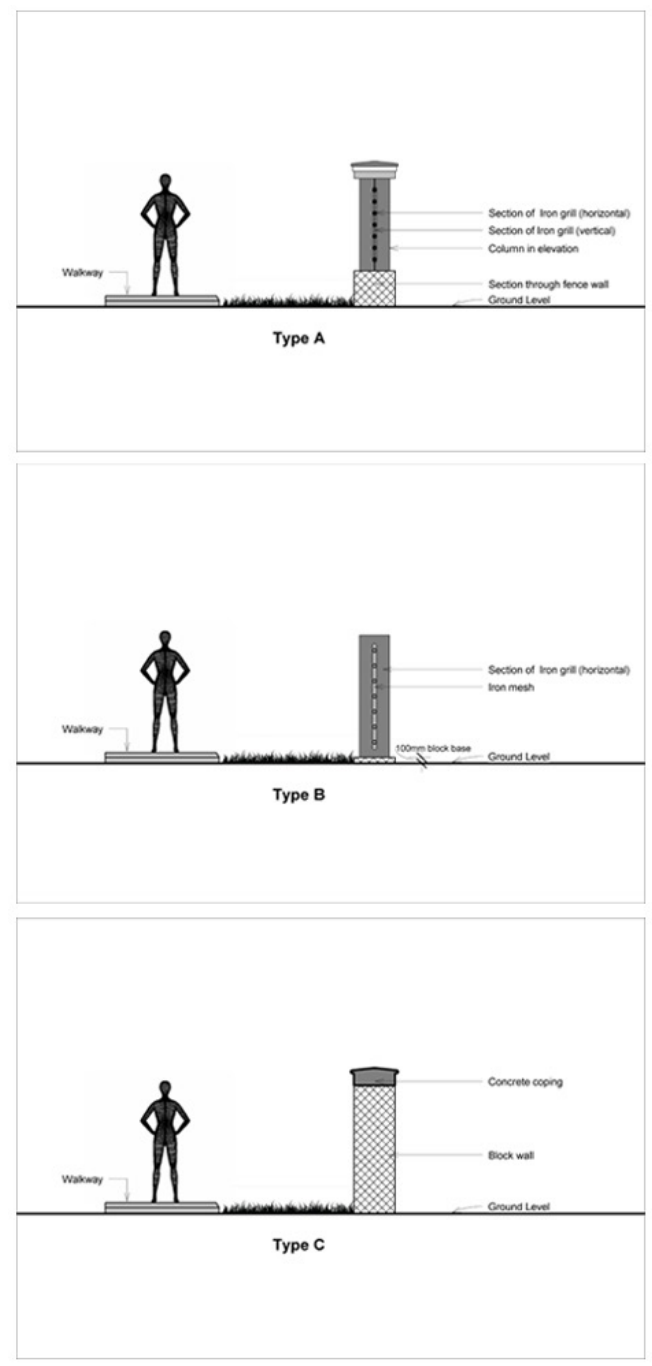

Figure 5. Structure of Common Fences

\section{Type of Climbers on Fences}

In determining the type of climbers to provide for the hybrid fences the major consideration in the amount of visibility intend for the premises and also the carrying capacity of the iron support or mesh. The other consideration is the suitability of the climbing plants to the environment, hence the advice for the use of local plants that have climbing characteristics. The climate of Rwanda plays a major role in ensuring that these plants survive well with minimum watering but the same might not be obtainable in the case of Nigeria where the weather is different, although there 
are local plants that can climb and survive. The process of watering the flowers in offices could also be extended to these climbers through the use of the concept of spot watering which ensures that water is not wasted. The density of the climbers can be determined with the assistance of landscape specialists, an initial dense situation could be created with the possibility of pruning down as the climbers mature and take shape thereby reducing the weight and water requirement without compromising the visibility requirement as shown in Figure 6. There are cases where the fence is embedded within rows of shrubs that are kept at the height of the fence and allowed to spread across, these shrubs are made to perform the function of climbers and they do not add any weight to the fence or the iron grill as they are self-supporting plants.
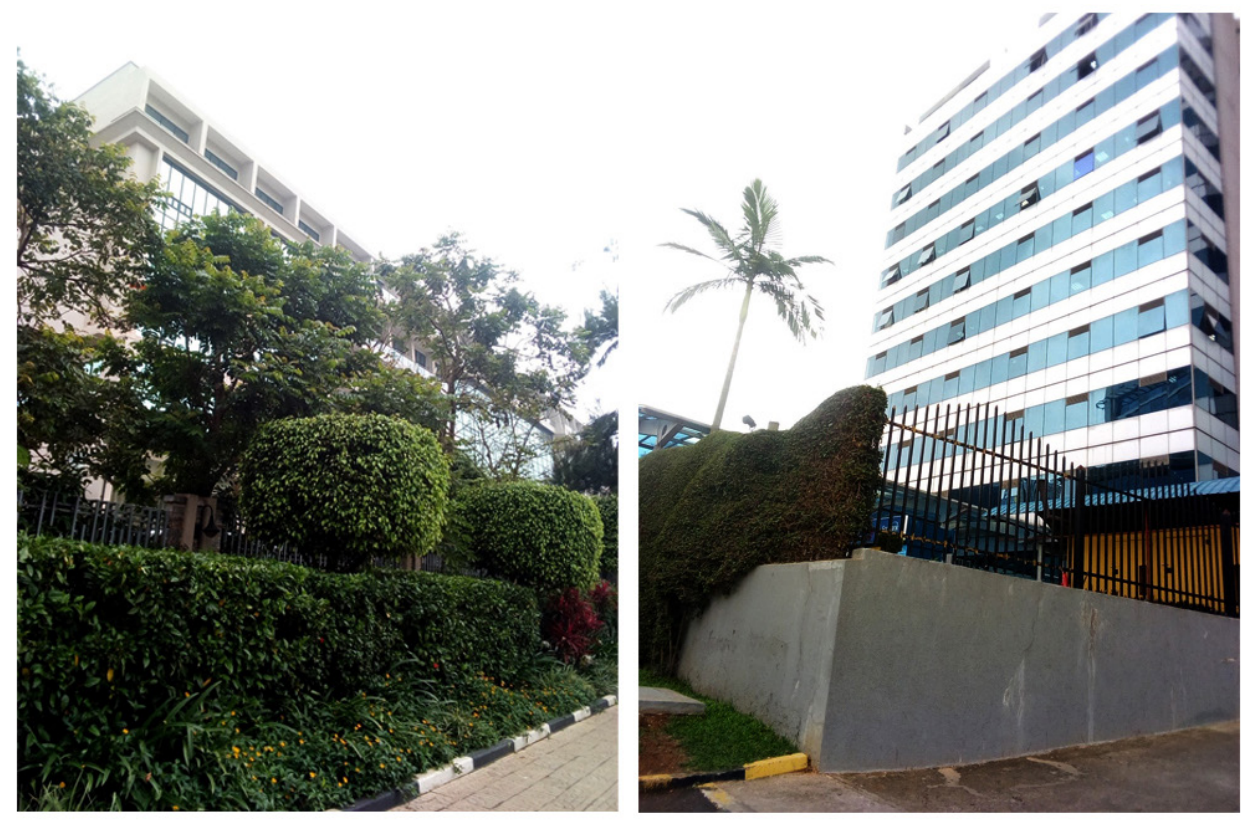

Figure 6. Example of Fences with Shrubs and Climbers

\section{Visibility through Fences}

The reasons for erecting a fence on a property vary amongst property owners or even administrators. A common function achieved with the fence is that it helps demarcate the property from others, while it is used to provide an image of the company or the owner. In terms of security, the fence is used to restrict movement and prevent unlawful incursion into the property, hence many public buildings in busy sections of the city of Abuja always try to prevent a direct view into their premises from the road through the use of wall fences. The need to ensure a lack of visibility into the premises often supersedes the need to achieve environmental sustainability and it is a common excuse given by some of the architects interviewed. They are quoted saying "If you cannot see inside the compound, it 
will be difficult for the building to be robbed and security camera will easily make possible to watch those loitering around; security before sustainability".

If the statement is a reflection of the architects involved in designing public buildings in Abuja, then one will understand why the city is referred to as a jungle of concrete. The security challenges in Kigali are quite different from those of Abuja and one might assume that this is the reason why the fences, usually the hybrid fences in some cases allow visibility. In Figure 7, it can be observed that there are variants of the hybrid fences that do not allow visibility into the premises from the road, these easily fit into the need stated as the basis for the choice of the walled fences while ensuring the sustainability required for the city. It is possible to make use of a combination free-standing shrubs and climbers which will increase the densification of the green part of the fence which reduces the visibility from the road.

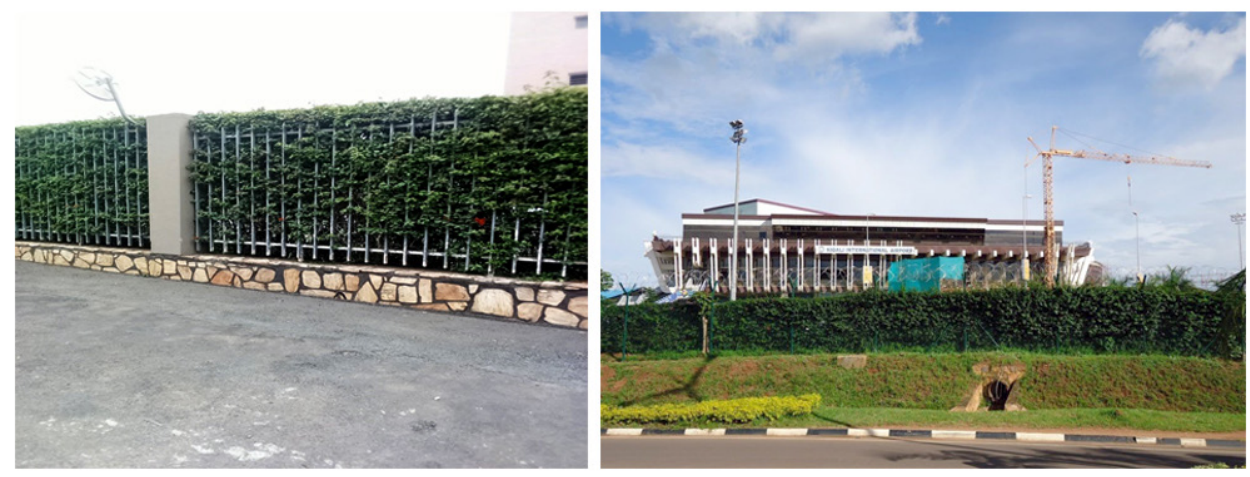

Figure 7. Reduced Visibility Through the Fence

\section{Sustainable Application Concept for Existing Wall Fences}

Based on the changing climate and the need to ensure sustainability in the cities, the recurring question from the architects interviewed was "How do we improve the existing fences and make them environmentally sustainable and enjoy the benefits?".

In responding to this question, there is a need to ensure that waste is not created through the reconstruction of the fences. Possible suggestions that could be adapted to handle the challenge as provided in Figure 8 where Types A and B show the possibility of providing a variant of the hybrid fence.

In Types A and A+ fence suggestion, the existing fence is fitted with short iron rods drilled into the wall with a little portion of $100 \mathrm{~mm}$ to $150 \mathrm{~mm}$ protruding out that would serve as the path for the climbers. The arrangement of these sprouts should be such that they do not weaken the structural integrity of the fence. The sprouts can then be connected with a lighter weighing iron rod is used to connect the sprouts in a manner that allows for easier climbing. 


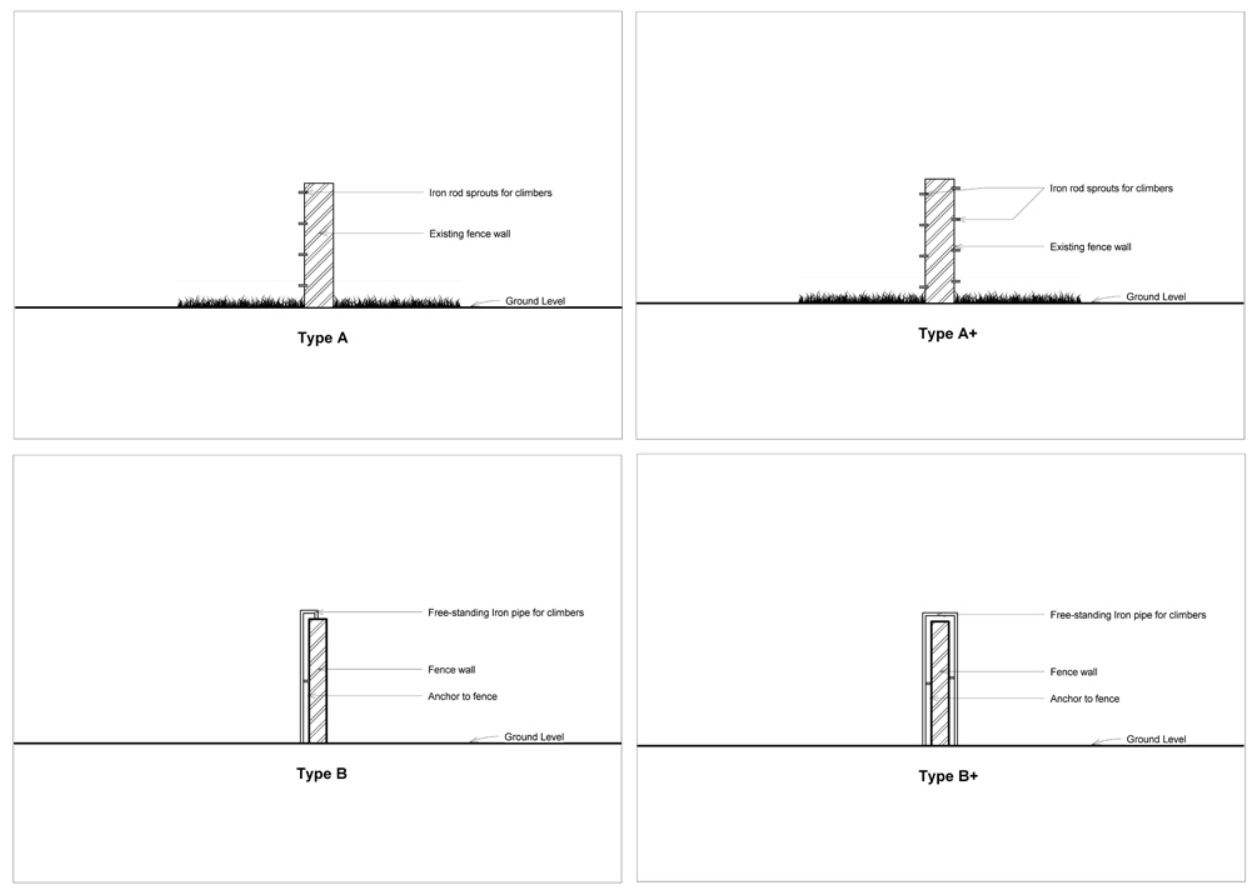

Figure 8. Concepts of Hybrid Fence for Existing Wall Fences

In Types B and B+ fence, the concept is slightly different as it requires freestanding iron grills or meshes fixed to the ground at a distance of $100 \mathrm{~mm}$ to $150 \mathrm{~mm}$ from the walled fence, at certain selected points the iron grill or mesh is anchored to the fence. The advantage of this Type B fence is that it offers the opportunity to use hollow pipes for the production of the iron mesh or grill and it is free standing hence reducing the load on the initial wall fence.

The use of either of the options will ensure that the initial walled fence forms the inner core of the fence and does not allow the concrete or sandcrete part to make contact with the sun hence reducing the heat gain. This new fence developed from either of the options will ensure that some form of environmental sustainability is achieved. The idea can be replicated on the other side of the fence to ensure complete compliance with the environment.

\section{Benefits of Hybrid Fence}

The benefits that could be derived from the use of hybrid fences in public buildings are quite numerous when compared to the problems associated with disuse. In the interview conducted amongst selected architects, they claimed that apart from the easily noticeable sustainability benefit, the ability to adapt the hybrid concept to existing wall fences is a good concept. A participant is quoted saying that "the fact that one does not need to destroy the existing fence will make it easier to convince the client to key into the scheme and this will ensure the need perception of security". 
The issue of placement of security cameras in positions where are not easily visible to the pedestrian makes the concept interesting and acceptable based on "the fact that there are spaces behind the mesh for the climbers ensures that cameras can be placed at strategic points without a direct view to people".

Every architect is always interested in ensuring that his buildings are quite interesting and appreciated by all while the first point of appreciation is the fence of the property. The possibility of getting flowers that are colourfully incorporated in the hybrid fence makes this concept valuable because:

The use of iron rods as a basis for the design of the mesh for support of the climbers and also the opportunity to select different flower types means that the fences could be given a whole new appearance which would attract attention or take attention away from the premises.

In examining the benefits of the variants of the hybrid fence, it is clear from the opinions of the architects that this type of fences would be of beneficial effects to the owners of the properties as they can choose the type of greenery to adopt in the fence. It was a unanimous opinion that the use of the hybrid fences would not affect nor compromise the security sought for by the clients, they equally agreed that it should be a part of the design requirements particularly in cities where it is not the case. A summary of the findings between the two cities as shown in Table 1 supports the argument for improvements and application of highbred fences.

Table 1. Summary of Comparison of Findings between Kigali and Abuja

\begin{tabular}{|c|c|c|c|c|}
\hline & Variable & Kigali & Abuja & Observation \\
\hline 1. & Policy issues & $\begin{array}{l}\text { Clear documented } \\
\text { statements on the use } \\
\text { on nature of fences } \\
\text { including the type of } \\
\text { materials for use. }\end{array}$ & $\begin{array}{l}\text { The policy is neither } \\
\text { clear nor available. } \\
\text { Interviews show } \\
\text { that the nature of } \\
\text { the fence is not } \\
\text { specified. }\end{array}$ & $\begin{array}{l}\text { The policy on } \\
\text { fences in Kigali } \\
\text { can be modified } \\
\text { and adopted in } \\
\text { Abuja. }\end{array}$ \\
\hline 2. & $\begin{array}{l}\text { Setbacks from } \\
\text { road and infill of } \\
\text { space }\end{array}$ & $\begin{array}{l}\text { The setbacks are well } \\
\text { defined from the road } \\
\text { to the fence. The } \\
\text { spaces are filled with } \\
\text { lawns, flowers and } \\
\text { walkways. }\end{array}$ & $\begin{array}{l}\text { Undefined setbacks } \\
\text { from roads which } \\
\text { are often left } \\
\text { unused. }\end{array}$ & $\begin{array}{l}\text { There is a } \\
\text { landscaping } \\
\text { opportunity for } \\
\text { the aesthetic } \\
\text { value which } \\
\text { could restrict } \\
\text { movements close } \\
\text { to the fences. }\end{array}$ \\
\hline 3. & $\begin{array}{l}\text { Categories of } \\
\text { fences }\end{array}$ & $\begin{array}{l}\text { There are several } \\
\text { variants of fences, } \\
\text { however there the } \\
\text { inclusion of green } \\
\text { elements ensured } \\
\text { that the fences } \\
\text { appeared sustainable } \\
\text { and improved the } \\
\text { environment. }\end{array}$ & $\begin{array}{l}\text { Many cases of } \\
\text { monolithic material } \\
\text { fences. In the case } \\
\text { where hybrid fences } \\
\text { occurred, it did not } \\
\text { have any green } \\
\text { element. }\end{array}$ & $\begin{array}{l}\text { Sustainability } \\
\text { could be } \\
\text { improved } \\
\text { using green } \\
\text { elements on the } \\
\text { fences and also } \\
\text { improvement of } \\
\text { security. }\end{array}$ \\
\hline
\end{tabular}


Table 1. (continued)

\begin{tabular}{|c|c|c|c|c|}
\hline & Variable & Kigali & Abuja & Observation \\
\hline 4. & $\begin{array}{l}\text { The basic } \\
\text { structure of } \\
\text { fences }\end{array}$ & $\begin{array}{l}\text { The structure of the } \\
\text { fences is made of low } \\
\text { walls and iron grill for } \\
\text { the climbers. }\end{array}$ & $\begin{array}{l}\text { High wall fences } \\
\text { with little options for } \\
\text { climbers. }\end{array}$ & $\begin{array}{l}\text { The basic fence } \\
\text { structure in use } \\
\text { in Kigali can be } \\
\text { adapted for } \\
\text { general use. }\end{array}$ \\
\hline 5. & $\begin{array}{l}\text { Type of climbers } \\
\text { on fences }\end{array}$ & $\begin{array}{l}\text { The use of local plants } \\
\text { allows for survival of } \\
\text { the plants based on } \\
\text { adaptation to climate. }\end{array}$ & $\begin{array}{l}\text { The climbers are } \\
\text { not available as this } \\
\text { is not a common } \\
\text { feature in the } \\
\text { fences. }\end{array}$ & $\begin{array}{l}\text { The use of hybrid } \\
\text { fences should } \\
\text { allow for local } \\
\text { plants to be } \\
\text { applied. }\end{array}$ \\
\hline 6. & $\begin{array}{l}\text { Visibility through } \\
\text { fences }\end{array}$ & $\begin{array}{l}\text { The close-fitted nature } \\
\text { of the climbers and } \\
\text { plants reduces and } \\
\text { eliminate direct view } \\
\text { through the fences. }\end{array}$ & $\begin{array}{l}\text { The use of concrete } \\
\text { wall eliminates views } \\
\text { through the fence. }\end{array}$ & $\begin{array}{l}\text { The hybrid options } \\
\text { as applied in } \\
\text { Kigali offers better } \\
\text { advantages. }\end{array}$ \\
\hline
\end{tabular}

\section{CONCLUSION AND RECOMMENDATION}

The clear definition of the laws in design and construction of fences in Rwanda shows that careful attention has been paid to details of how they would want their city to appear, the same cannot be said of Nigeria and several reasons could be adjudged for with. The key issue as observed in this article is that the architects practising in Kigali are aware of the rules governing the use of fences and they have been able to ensure that their clients follow through and there are always regular checks by the authority. This regular check is important in the case of Abuja where an examination of the fences provided did not connote the clear understanding or application of the law. The hybrid fence as proposed in the article would ensure that in implementing the law the existing fences are not destroyed and that within a period the city can become green. The willingness shown by the architects and the benefits stated shows that cities with existing walled fences could be made greener while adopting other variants for new fences.

The article recommends that there is a need for a clear policy or law on the remodelling of existing wall fences and new fences in cities where none exist as in the case of Abuja. Architects should be encouraged to seek other opportunities of improving the environmental sustainability of the buildings they design and with the view of determining areas of increasing the greenery.

\section{REFERENCES}

Anunobi, A.I., Adedayo, O.F., Ayuba, P., Oyetola, S.A. and Otijele, G.O. (2016). An assessment of ramp designs as barrier-free accesses in public buildings in Abuja, Nigeria. Centre for Human Settlements and Urban Development Journal, 6(1): 119-131. 
Capital Fence and Wire Ltd. (2017). Hybrid privacy. Available at: http://capitalfence. ca/hybrid-privacy-300040004500-series/.

Dorn, M., Atlas, R., Schneider, T., Dorn, C., Nguyen, P., Satterly, S., Bentley, R. and Ellis, R. Goble, C., Bellaire, U., Wilson, R. and Billinger, M. (2014). Seven Important Building Design Features to Enhance School Safety and Security. Macon, GA: Safe Havens International Inc. Available at: https://safehavensinternational. org/wp-content/uploads/2014/12/Seven_Important_Building_Design_ Features_to_Enhance_School_Safety_and_Security-ISSSA_2014.pdf.

Federal Emergency Management Agency (FEMA) (2003). Site and layout design guidance. In Reference Manual to Mitigate Potential Terrorist Attacks against Buildings: Providing Protection to People and Buildings. Washington DC: FEMA. Available at: https://www.fema.gov/media-librarydata/20130726-1455-20490-7805/fema426_ch2.pdf.

Georgiou, M. (2006). Architectural privacy a topological approach to relational design problems. MSc diss., University College London.

HM Government (2006). Better Public Building. London: Commission for Architecture and the Built Environment and the Department for Culture, Media and Sport.

Hull, S., Sehume, T., Sibiya, S., Sothafile, L. and Whittal J. (2016). Land allocation, boundary demarcation and tenure security in tribal areas of South Africa. South African Journal of Geomatics, 5(1): 68-81. https://doi.org/10.4314/sajg. v5il.5.

Kim, S. and Kwon, H. (2018). Urban sustainability through public architecture. Sustainability, 10(1249): 1-21. https://doi.org/10.3390/su10041249.

Lee, Y. (2008). "Designing with users, how?": Investigate users' involvement tactics for effective inclusive design processes. Paper presented at the International DMI Education Conference on Design Thinking: New Challenges for Designers, Managers and Organizations. Cergy-Pointoise, France, 14-15 April.

Libecap, G.D. and Lueck, D. (2011). The demarcation of land and the role of coordinating property institutions. Journal of Political Economy, 119(3): 426467. https://doi.org/10.1086/660842.

Meara, S.P.O. (2014). School security design: Planning to mitigate risk and avoid liability. The Construction Lawyer, 34(1): 1-9.

Mumovic, D. and Santamouris, M. (2009). A Handbook of Sustainable Building Design and Engineering: An Integrated Approach to Energy, Health and Operational Performance. London: Earthscan.

Oyetola, S.A., Adedayo, O.F., Anunobi, A.I., Adebisi, G.O. and Eri, P.O. (2015). Should public buildings be exclusive? A study of selected institutional buildings in Minna, Niger State. American Journal of Engineering Research (AJER), 4(3): $81-87$.

Raeisi, I., Nezhad, A.K. and Hafezifar, M. (2010). Architectural design principles of public spaces based on social sustainability approach: A case study in Ardabil, Iran. Design Principles and Practices: An International Journal, 4(5): 99-1 13. https://doi.org/10.18848/1833-1874/CGP/v04i05/37968.

Sadeghi, G., Sani, R.M. and Wang, R. (2015). Symbolic meaning of transparency in contemporary architecture: An evaluation of recent public buildings in Famagusta. Current Urban Studies, 3(4): 385-401. https://doi.org/10.4236/ cus.2015.34030. 
The Protection Engineering Group, Inc. (2011). Security Master Plan: Physical Security Design Criteria. Chantilly, VA: The Protection Engineering Group, Inc. Available at: https://docplayer.net/818255-Security-master-plan-physicalsecurity-design-criteria.html.

Wong, H. (2014). Architecture without barriers: Designing inclusive environments accessible to all. MSc diss., Ryerson University, Toronto.

Zahner Group (2017). Passive Security in Architecture: Designing for Security without Sacrificing Beauty. Kansas City, MO: A. Zahner Company. Available at: https://www.azahner.com/blog/passive-security-in-architecture.

Zhang, Y. and Yu, J. (2013). A study on the building of urban public security management network platform. Procedia Engineering, 52: 613-617. https:// doi.org/10.1016/j.proeng.2013.02.194. 